\title{
REVIEW
}

UDC 578.834.1

doi: https://doi.org/10.15407/ubj92.03.006

\section{COVID-19 INFECTION: DISEASE MECHANISM, VASCULAR DYSFUNCTION, IMMUNE RESPONSES, MARKERS, MULTIORGAN FAILURE, TREATMENTS, AND VACCINATION}

\author{
S. G. VARI \\ International Research and Innovation in Medicine Program Cedars-Sinai Medical Center, \\ Los Angeles, CA, USA; \\ e-mail: vari@cshs.org
}

Received: 06 August 2020; Accepted: 11 August 2020

The new SARS-CoV-2 virus is a great danger for the worldwide population since there is no known pre-immunity, no specific treatment, and no vaccine. Still, the testing and tracing are the best tools to isolate the infected and prevent the spread of COVID-19. The major goals are to save lives, reduce the mortality rate, increase the survival rate of those are in severe or critical conditions, reduce the hospital stay and accelerate the recovery. This review summarizes the findings on the novel coronavirus that causes COVID-19 and outlines information about symptoms, testing, disease mechanism, vascular dysfunction, immune responses, treatments, and vaccination. At this time no vaccine is available to prevent COVID-19. A literature review reveals that more research is necessary to investigate the interactions between respiratory viruses, human coronaviruses, and the new SARS-CoV-2 virus in the infected population to guide the design of COVID-19 specific therapeutics and vaccines. Almost every government on earth has realized that daily life cannot return to normal until citizens have built up antibodies to safeguard them from the virus. Scientists and manufacturers worldwide are accelerating COVID-19 vaccine research, and pharmaceutical companies are already investing in the large-scale production of vaccines. A synopsis of the most recent sources presented in this review was the starting point for several COVID-19 research projects in the Regional Cooperation for Health, Science and Technology (RECOOP HST) Association managed by Cedars-Sinai Medical Center to gain a better understanding of the COVID-19 disease.

K e y w or d s: COVID-19 infection, symptoms, testing, disease mechanism, immune responses, vascular dysfunction, multiorgan failure, markers, treatments, and vaccination.

\section{Mixed messages}

On a daily basis the scientific journals bombard physicians and scientists with important, or sometimes "voodoo" information (to heal or do magic), treatment options for SARS-CoV-2 infections. The public and medical communities, confused by the mixed messages they are constantly getting from the vastly undereducated politicians can make inconsistent statements or controversial decisions. Unfortunately, these politicians are the opposite of the voodoo people, since their spirit cannot speak for the infected people who passed away due to their negligence, but they are and will continue creating disastrous consequences for our lives.

\section{Facts about the COVID-19 infection}

The latest data show that 80 percent of the people who become infected with the COVID-19 novel coronavirus will experience a mild or moderate form of disease. Roughly 15 percent will develop a severe form of the disease requiring hospitalization, and some 5 percent will become critically ill. The

(C) 2020 Vari S. G. This is an open-access article distributed under the terms of the Creative Commons Attribution License, which permits unrestricted use, distribution, and reproduction in any medium, provided the original author and source are credited. 
industrialized countries have sophisticated health care systems and may be able to cure some critically ill patients, but the danger is that even the most advanced systems may be overwhelmed by the large numbers of people who will need to be hospitalized. The less developed countries are struggling with increasing numbers of patients, lack of trained health care workers, insufficient intensive care unit capacity and shortage of medications all of which together put patient care and the entire population at risk.

\section{Spectrum of symptoms}

The coronavirus infection actually has a spectrum of symptoms (Table 1) [1].

Asymptomatic people are the super infectors and comprise up to $40 \%$ of infected individuals.

The majority of the infections are mild or moderate, and they are $30 \%$ of the COVID-19 population. These individuals have flu-like symptoms, are not hospitalized, and recover at home.
Mild symptoms include a runny nose, sore throat, congestion, and dry cough. In this stage, activation of Natural Killer (NK) cells are pivotal effectors of the innate immunity, and protect individuals from the viral infection. NK cells are the first line of defense against invading viruses, given their substantial ability to directly target infected cells without the need for specific antigen presentation. NK cells can also amplify and modulate antiviral adaptive immune responses. By establishing cellular networks with a variety of cell types, such as dendritic cells that capture antigens with their threadlike tentacles and present the antigens to T lymphocytes ( $\mathrm{T}$ cells), an immune response is stimulated.

Moderate symptoms include high fever, tiredness and fatigue, and chest pain. In this stage, macrophages produce high amounts of TNF, IL-1, IL-6, IL-8, and IL-12 that spread throughout the patient's body.

Patients with severe symptoms represent $15 \%$ of the infected patient population. In this stage, the

Table 1. Spectrum of symptoms and disease stage

\begin{tabular}{|c|c|c|}
\hline Affected Organs & Symptoms & Stages \\
\hline & Asymptomatic & Super infectors \\
\hline \multirow[t]{4}{*}{ General } & A Fever Spike or High Fever & $\begin{array}{l}\text { Mild, Moderate, Severe, } \\
\text { Critical }\end{array}$ \\
\hline & Tiredness and Fatigue & $\begin{array}{l}\text { Mild, Moderate, Severe, } \\
\text { Critical }\end{array}$ \\
\hline & Chills or Repeated Shaking & Severe, Critical \\
\hline & Excruciating Headache & Moderate, Severe, Critical \\
\hline \multirow[t]{4}{*}{ Respiratory } & Runny Nose, Sore Throat, and Congestion & Mild, Moderate \\
\hline & Dry Cough & Mild, Moderate \\
\hline & Chest Pain & Moderate, Severe, Critical \\
\hline & Breathlessness & Moderate, Severe, Critical \\
\hline \multirow[t]{2}{*}{ Gastrointestinal } & Reduced Appetite & Mild, Moderate \\
\hline & Diarrhea or Nausea & Moderate, Severe \\
\hline \multirow[t]{2}{*}{ Skin } & COVID Rashes & Mild, Moderate \\
\hline & "COVID Toes"(purple lesions on feet and hands) & Mild, Moderate \\
\hline Eye & $\begin{array}{l}\text { Pink Eye (Note: If patient recently suffered } \\
\text { from conjunctivitis, a.k.a. "pink eye", it } \\
\text { could have been due to COVID-19) }\end{array}$ & Mild, Moderate \\
\hline Sensorial & Reduced or Loss of, Sense of Taste and Smell & Mild, Moderate \\
\hline Musculoskeletal & Muscle Pain & Mild, Moderate \\
\hline Mental & $\begin{array}{l}\text { Disorientation, Loss of Speech or } \\
\text { Movement, Forgetfulness }\end{array}$ & Moderate, Severe \\
\hline
\end{tabular}


intense production of cytokines causes Respiratory Distress Syndrome. The patient has shortness of breath, increased blood pressure, and decreased oxygen saturation. Also in this stage, endothelial cells increase production of cytokines that could trigger thrombosis.

Patients in the Critical Stage constitute about $5 \%$ of the infected population. They develop Severe Acute Respiratory Syndrome (SARS) caused by the Cytokine Storm, and experience high fever, chest pain and breathlessness [2].

The median time from onset to clinical recovery for mild cases is approximately 2 weeks and for severe or critical disease is 3-6 weeks [3].

\section{High risk population}

People of all ages can be infected by the COVID-19 novel coronavirus. The high-risk population comprises individuals who are older than 60 years and/or have pre-existing medical conditions such as diabetes, heart disease, respiratory disease and hypertension. These individuals are more vulnerable to becoming severely ill with the virus $[4,5]$.

\section{Sex difference}

The literature tells us that sex is an important driver of the morbidity and mortality risk in the COVID-19 pandemic. There is evidence that sex hormones can modulate the expression of angiotensin-converting enzyme 2 (ACE2), and this information may help us understand the COVID-19 epidemiological results that demonstrate a sex difference. An enzymatic system involved in this different predisposition between sexes could be represented by ACE2 that is activated and down-regulated by the spike protein of the virus and allows the penetration of SARS-CoV-2 into epithelial cells. Recently published data show that the SARS-CoV-2 virus present in myocardium displays a sex difference [6].

Most importantly we have learned that as the COVID-19 pandemic has worsened, the subdivided sex data can help guide patient care and therapeutic management. These data also address the question of whether or not older men with co-morbidities require additional prevention, surveillance or earlier intensive intervention than women [7].

\section{Social effects - stress}

The worldwide spread of the SARS-CoV-2 viral infection has challenged societies and individuals. The isolation and [anti-] social distancing create psy- chosomatic stress on individuals, on families, and on relationships. In health care facilities, the overload of patients and the constant danger of SARS-CoV-2 viral infections are creating endless stressors and chronic stress [8].

\section{Testing for COVID-19}

Viral tests check samples from the respiratory system, such as a swab from the inside of the nose, to see if the individual is currently infected with SARS-CoV-2, the virus that causes COVID-19.

There are three types of tests available that can detect whether a person currently has COVID-19 or has had it in the past (Table 2). Polymerase chain reaction (PCR) tests for active infection. The antigen test for active infection uses antibodies that are produced in animals to hunt for proteins embedded on the coronavirus' surface. Serology testing, which tests looks for antibodies against SARS-CoV-2 from a past infection $[9,10]$.

\section{Measures of efficacy [10]}

Sensitivity: Sensitivity is sometimes called the "true positive rate." It measures how frequently the test is positive when the person being tested actually has the disease.

Specificity: Specificity is sometimes called the "true negative rate." It measures how frequently the test is negative when the person being tested does not have the disease.

Positive Predictive Value: Positive predictive value is a measure of how likely it is that a positive test is a true positive rather than a false positive. This is dependent on how many people in the population being tested have had the disease.

\section{The mechanism(s) underlying the infection}

Coronavirus. Coronaviruses belong to a large family of viruses, and most of them are harmless for humans. Four types are known to cause colds, and two other types can cause severe lung infections: Severe Acute Respiratory Syndrome (SARS) and Middle East Respiratory Syndrome (MERS). The novel coronavirus is now known as SARS$\mathrm{CoV}-2$, because of its similarities to the virus that causes SARS. From a review of the literature, it became apparent the Dr June Almeida identified the coronavirus in 1964 at her laboratory in St Thomas's Hospital in London. In 1967 her first photographs were published in the Journal of General Virology and Dr Almeida, along with Dr Tyrrell and Prof 
Table 2. COVID-19 tests

\begin{tabular}{|c|c|c|}
\hline \multicolumn{2}{|c|}{ Tests for active infection } & Antibody tests for past infection \\
\hline PCR test & $\begin{array}{l}\text { Antigen test } \\
\end{array}$ & Serology test \\
\hline $\begin{array}{l}\text { PCR test looks for the virus itself } \\
\text { in the nose, throat, or other areas in } \\
\text { the respiratory tract to determine } \\
\text { if there is an active infection with } \\
\text { SARS-CoV-2. PCR tests - the } \\
\text { swab tests that look for viral RNA } \\
\text { - are currently the most common } \\
\text { way to test for an active SARS- } \\
\text { CoV-2 infection and can take up to } \\
\text { four days to perform. }\end{array}$ & $\begin{array}{l}\text { Similar tests are done routinely in } \\
\text { clinics for influenza all the time. } \\
\text { SARS-CoV-2 antigen test uses } \\
\text { antibodies that are produced in } \\
\text { animals to catch the proteins } \\
\text { embedded on the coronavirus } \\
\text { surface. If the antibodies detect } \\
\text { viral proteins in a sample, the } \\
\text { person most likely has the } \\
\text { coronavirus. }\end{array}$ & $\begin{array}{l}\text { Serology test looks for antibodies } \\
\text { against SARS-CoV-2 in the blood } \\
\text { to determine if there has been } \\
\text { an infection in the past. IgM is } \\
\text { the first antibody that is formed } \\
\text { against a germ, so it appears } \\
\text { on tests first, usually within } 1-2 \\
\text { weeks. The body then forms IgG, } \\
\text { which appears on tests about } 2 \\
\text { weeks after the illness starts. IgM } \\
\text { usually disappears from the blood } \\
\text { within a few months, but IgG can } \\
\text { last for years. Some antibody tests } \\
\text { detect IgM and IgG, and other } \\
\text { tests detect only IgG. }\end{array}$ \\
\hline $\begin{array}{l}\text { In most cases, a nose or throat } \\
\text { swab is taken by a health care } \\
\text { professional, and that swab is sent } \\
\text { to the lab for testing. }\end{array}$ & $\begin{array}{l}\text { An antigen test for SARS- } \\
\mathrm{CoV}-2 \text { starts with a health care } \\
\text { professional collecting a sample of } \\
\text { mucus from the back of a person's } \\
\text { throat or nose using a swab. }\end{array}$ & $\begin{array}{l}\text { Health care professionals collect a } \\
\text { blood sample for the test. }\end{array}$ \\
\hline $\begin{array}{l}\text { A positive PCR test means that the } \\
\text { person being tested has an active } \\
\text { COVID-19 infection. }\end{array}$ & $\begin{array}{l}\text { The swab is dipped into a liquid to } \\
\text { dissolve the mucus and release the } \\
\text { virus. The virus-containing liquid } \\
\text { is applied to the surface of a test } \\
\text { slide that is coated with antibodies. } \\
\text { A second mixture of antibodies } \\
\text { is applied to the slide. These } \\
\text { antibodies have been chemically } \\
\text { modified with a dye that makes } \\
\text { them visible to the naked eye or } \\
\text { detectable by fluorescent light. If } \\
\text { there is no detectable dye, it means } \\
\text { the person does not have SARS- } \\
\text { CoV-2 or the sample did not have } \\
\text { enough viral proteins. }\end{array}$ & $\begin{array}{l}\text { A positive antibody test means } \\
\text { that the person being tested } \\
\text { was infected with SARS-CoV-2 } \\
\text { in the past and their immune } \\
\text { system developed antibodies to } \\
\text { fight the COVID-19 infection. } \\
\text { PCR can be used to determine } \\
\text { who has an active infection. }\end{array}$ \\
\hline
\end{tabular}

Tony Waterson, named it coronavirus because of the crown or halo surrounding it on the viral image [11-13].

\section{SARS-CoV-2 virus}

The molecular biology of SARS-CoV-2 is revealed through the use of direct RNA sequence data, enabling a detailed view of the viral subgenomelength mRNA architecture. Only $\alpha$ and $\beta$ coronavi- ruses have the ability to infect humans. The main cause of animal to human transmission of the virus is consumption of an infected animal. The infected person further transmits the virus to healthy persons by droplet, vapor, handshake, hug, or kiss [14, 15]. SARS-CoV-2 has a major structural protein spike (S) and attracted great attention because the virus recognizes the angiotensin-converting enzyme 2 (ACE2) receptor. The SARS-CoV-2 virus binds to 


\section{Table 2. Continuation}

PCR can help identify people who
are contagious to others.

PCR can help identify people who are contagious to others.
Antigen tests are far faster and The test identifies people who easier to perform than PCR tests. had an infection in the past, even The most time-consuming part of if they had no symptoms of the the antigen test process is waiting illness.

for the antibody mixtures and It can help public health authorities the sample to mix completely. A and researchers know what COVID-19 antigen test might take percentage of the population has only 15-30 minutes to complete already had COVID-19. and requires very little expertise.

It helps to determine who has some

\section{PCR:}

- Only helps determine whether a person has an active infection at the time of testing.

- Does not help determine who had an infection in the past.

- Does not help determine which people who have been exposed to SARS-CoV-2 will develop active infection during the 2 weeks after exposure.

In some people, the virus can only be found by PCR for a few days at the beginning of the infection, so the test might not find the virus if the swab is taken more than a few days after the illness starts.

In some people, the virus can be found by PCR in the nose and throat for several weeks, even longer than the time that they are actually contagious to other people.

This test requires certain kinds of swabs that may be in short supply. level of immunity to COVID-19. It helps to determine who qualifies as a donor of convalescent plasma (blood product that contains antibodies against SARS-CoV-2 and can be used as a COVID-19 treatment).

Helps to make decisions about who could safely work in certain jobs.

Helps to determine the time of the COVID-19 infection, since we know that IgM is formed before IgG and after two weeks $\operatorname{IgM}$ disappears and $\operatorname{IgG}$ persists.

It may be negative if it is used too close to the beginning of an infection, which is why it should not be used to detect active COVID-19 infection.

Some antibody tests have low sensitivity and specificity and so may not produce reliable results.

Some antibody tests may crossreact with other coronaviruses that are not SARS-CoV-2, the virus that causes COVID-19, leading to false test results. 
the receptor-binding motif (RBM) in the receptorbinding domain (RBD). ACE2 is distributed in many organs and cells, such as epithelial and endothelial cells $[16,17]$.

\section{Entry point is the lung}

SARS-CoV-2 binding to the ACE2 receptor requires the surface unit of the viral spike protein. In the lung, ACE2 expression occurs in type 2 pneumocytes and macrophages.

SARS-CoV-2 virus enters the respiratory system and the first point of entry is the ACE2 receptor. Block the ACE 2 receptor, and the epithelial cells become a "Trojan Horse". The virus replicates in the endoplasmic reticulum and surfacing to the blood stream in Golgi. The virus factory starts to work, and it initiates the innate natural immune reaction with lymphocytes: NK cells and cytotoxic T cells $[18,19]$. The inflamed lung tissue thickens and a barrier against oxygen penetration into blood vessels increases. In COVID-19 immunopathology, as the inflammation increases additional tissue damage is caused in the lung and also in the vascular system.

\section{Dissemination in the body via the cardiovascular system}

The vascular endothelium is an active paracrine, endocrine, and autocrine organ that is indispensable for the regulation of vascular tone and the maintenance of vascular homoeostasis. Endothelial dysfunction is a principal determinant of microvascular dysfunction by shifting the vascular equilibrium towards more vasoconstriction with subsequent organ ischemia, inflammation with associated tissue edema, and a pro-coagulant state [20, 21]. Recruitment of immune cells by SARS-CoV-2 infection and entry of the virus into endothelial cells can result in widespread endothelial dysfunction associated with apoptosis. The SARS-CoV-2 infection facilitates the induction of inflammation and immune response within the endothelium in blood vessels in several organs. Inductions of apoptosis and pyroptosis have a role in endothelial cell injury in patients with COVID-19, could explain the systemically impaired microcirculatory function in different organs [22].

\section{Change in blood coagulation during COVID-19}

Cardiovascular risk factors such as hypertension, hypercholesterolemia, diabetes mellitus, or chronic smoking stimulate the production of reactive oxygen species in the vascular wall. Nicotinamide adenine dinucleotide phosphate (NADPH) oxidases represent major sources of reactive oxygen species upregulated and activated in obesity, hypertension and diabetes [23]. Cardiovascular complications are rapidly emerging as a key threat in COVID-19 in addition to respiratory disease. The mechanisms underlying the disproportionate effect of SARS-CoV-2 infection in patients with cardiovascular comorbidities [24].

We have several unanswered questions about the nature of the coagulopathy associated with COVID-19. The level of D-dimer (a fibrin degradation product indicating thrombosis) in COVID-19 patients is significantly increased to levels above those in patients who have Deep Vein Thrombosis or Pulmonary Embolus and suggests hypercoagulability. Platelet adhesion or activation, and fibrin deposition as the result of coagulation constitute the fundamental processes of thrombus formation. The published literature on septic coagulopathy, monitoring prothrombin time (PT), D-dimer, platelet count, and fibrinogen can be helpful in determining the thrombotic factors $[25,26]$. D-dimer is a reliable and sensitive index of fibrin deposition and stabilization. Its presence in plasma should be indicative of thrombus formation. D-dimer can be used as a fibrin-related degradation marker for the diagnosis and management of patients with Disseminated Intravascular Coagulation (DIC). D-dimer is one of the most valuable markers of thrombosis-related clinical conditions in COVID-19 [27, 28].

\section{Obesity is the most common risk factor in COVID-19}

Obesity is associated with an increased risk of diabetes mellitus, cardiovascular disease and kidney disease, and these comorbidities are considered to result in increased vulnerability to COVID-19 pneumonia and associated organ failures. Obesity is shifting the severe form of COVID-19 disease to younger ages [29-33].

Since the discovery of leptin in 1994, it was revealed that many physiological functions such as modulation of vascular function, reproduction, bone metabolism, inflammation, infection, and immune responses, are influenced by central regulation of food intake, energy expenditure and hormone regulation via activation of the leptin receptor (LEPR). Leptin, the forerunner of the adipokine family, is a key sensor of energy metabolism and a cornerstone 
in the regulation of metabolism-immune system interplay. Leptin regulates both innate and adaptive responses through modulation of immune cell survival and proliferation as well as their activity. In innate immunity, leptin increases the cytotoxicity of NK cells and promotes the activation of granulocytes, macrophages and dendritic cells. Leptin activates B cells to secrete cytokines and modulates B cell development [34].

\section{Neurological or psychiatric disease in COVID-19}

The COVID-19 infection and consequent inflammation, endothelial dysfunction, and increased production of cytokines by endothelial cells could cause complications in the Central Nervous System (CNS) and Peripheral Nervous System (PNS) that result in neurological and psychiatric diseases. The majority of cerebrovascular disorders such as ischemic stroke, intracerebral hemorrhage, vasculitis, altered mental status with encephalopathy as well as, neuropsychiatric diagnoses including psychosis and neurocognitive (dementia-like) syndrome are consequences of endothelial or vascular dysfunction [35-37]. A recently published paper suggests that vagal dysfunction might contribute to thromboembolic incidents. This is an "egg or chicken - which came first" issue. The author proposes the opposite, that vagal dysfunction is the consequence of the endothelial dysfunction, and increased production of cytokines by endothelial cells [38].

\section{Search for markers to indicate multiorgan failure}

In the severe and critical stages of COVID-19, SARS, endothelial dysfunction, neuropathy and myopathy as well as kidney and other organ failure can occur $[39,40]$.

SARS-CoV-2 infects the host via the ACE2 receptor in the epithelial alveolar lining thereby causing lung injury. The ACE2 receptor is also widely expressed on endothelial cells, which traverse multiple organs. High risk patients with obesity often have respiratory dysfunction, which is characterized by alterations in respiratory mechanisms, increased airway resistance, impaired gas exchange and low lung volume and muscle strength. These individuals are predisposed to hypoventilation-associated pneumonia, pulmonary hypertension and cardiac stress [29]. Monitoring prothrombin time (PT), D-dimer, platelet count, and fibrinogen or other markers
(Table 3) could be helpful in determining prognosis in COVID-19 patients with severe or critical symptoms. If these parameters worsen, more aggressive intensive care support is necessary and consideration should be given for more targeted therapies and blood product support as appropriate. If these markers are stable or improving, it gives added confidence for less aggressive treatment as long as the clinical condition is corroborative [25].

In the frame of the International Research and Innovation in Medicine (IRIM) Program at CedarsSinai Medical Center, the Regional Cooperation for Health, Science and Technology (RECOOP HST) Association https://www.cedars-sinai.edu/Research/ Research-Administration/Recoop/ is enhancing research collaboration and providing platforms for scientific networking in life sciences within Central and Eastern European Countries as well as CrossAtlantic. In the COVID-19 pandemic, the RECOOP HST Association planned and implemented several COVID-19 projects: (1) SARS-CoV-2 virus Saliva Antibody Test; (2) Sex difference in chronic stress during COVID-19 lockdown of students; (3) Chronic stress study of SARS-CoV-2 infected seropositive patients and health care workers; (4) Impacts of COVID-19 infection on patients with high blood pressure using angiotensin-converting enzyme inhibitors (ACEIs) or angiotensin-receptor blockers (ARBs); and (5) Vascular Dysfunction in post infected COVID-19 patients. Three Ukrainian organizations are participating in the RECOOP COVID-19 projects:

I. Horbachevsky Ternopil National Medical University, Ternopil, Ukraine

Palladin Institute of biochemistry of NAS of Ukraine, Kyiv, Ukraine

Danylo Halytsky Lviv National Medical University, Lviv, Ukraine

\section{Available treatments and new developments}

Presently there are no antiviral drugs approved by the FDA to treat COVID-19. There is an urgent need for better therapies. Currently available treatments and new developments are shown in Table 4. The major goals are to save lives, reduce the mortality rate, increase the survival rate of those are in severe or critical conditions, reduce the hospital stay and accelerate the recovery. Patients admitted with COVID-19 at selected hospitals in the USA may now volunteer to enroll in a clinical trial to test the safety and efficacy of a potential new treat- 
Ta ble 3. Markers that could aid in the diagnosis and management of multiorgan failure

\begin{tabular}{|c|c|}
\hline \multicolumn{2}{|r|}{ Sex difference } \\
\hline Angiotensin-converting enzyme & Could demonstrate the gender difference \\
\hline \multicolumn{2}{|r|}{ Stress } \\
\hline Saliva cortisol level & High level of cortisol is related to sustained stress \\
\hline \multicolumn{2}{|r|}{ Immunization } \\
\hline Immunoglobulins $\mathrm{M}$ and $\mathrm{G}$ & $\begin{array}{l}\text { The antigens of SARS-CoV- } 2 \text { could be } \\
\text { detected in saliva and serum by ELISA }\end{array}$ \\
\hline \multicolumn{2}{|r|}{ Inflammation } \\
\hline Protein C level & Indicates inflammation at a very sensitive level \\
\hline Cytokines IL-1, IL-6, IL-18 and IFN $\gamma$ & $\begin{array}{l}\text { Well-established markers of acute } \\
\text { and chronic inflammation }\end{array}$ \\
\hline Leptin & Proinflammatory cytokine produced mainly by adipocytes \\
\hline \multicolumn{2}{|c|}{ Pulmonary capillary barrier dysfunction } \\
\hline Arginase & $\begin{array}{l}\text { Mediator of pulmonary capillary } \\
\text { barrier dysfunction (hypoxia) }\end{array}$ \\
\hline \multicolumn{2}{|c|}{ Endothelial dysfunction } \\
\hline Thrombomodulin & $\begin{array}{l}\text { Concentration correlates with endothelial } \\
\text { dysfunction and oxidative stress }\end{array}$ \\
\hline Endothelin-1 & $\begin{array}{l}\text { Reduced oxygen saturation in the blood } \\
\text { increases endothelin production }\end{array}$ \\
\hline Soluble E-selectin & $\begin{array}{l}\text { Elevation of E-selectin concentration } \\
\text { correlates with endothelial dysfunction }\end{array}$ \\
\hline Peroxynitrite level & $\begin{array}{l}\text { Indicates the formation of hydroxyl radicals and } \\
\text { nitrogen dioxide, resulting in vascular disorders }\end{array}$ \\
\hline \multicolumn{2}{|r|}{ Oxidative stress } \\
\hline Glutathione & Very reliable and stable indicator of oxidative stress \\
\hline \multicolumn{2}{|r|}{ Thrombosis } \\
\hline D-dimer & $\begin{array}{l}\text { Reflects degradation of covalently cross-linked } \\
\text { (stabilized) fibrin and indicates formation of } \\
\text { intravascular thrombus and its fibrinolysis }\end{array}$ \\
\hline Fibrinogen level & $\begin{array}{l}\text { Shows increased level in procoagulant potential } \\
\text { of blood coagulation system. Fibrinogen is also } \\
\text { a protein of acute phase of inflammation }\end{array}$ \\
\hline $\begin{array}{l}\text { Partial-products of prothrombin } \\
\text { activation (prethrombin, fragment 1-2) }\end{array}$ & $\begin{array}{l}\text { Being products of prothrombin autolysis by thrombin, } \\
\text { indicate generation of active thrombin in blood }\end{array}$ \\
\hline Protein C level & $\begin{array}{l}\text { Main protein of anticoagulant system that } \\
\text { also possess anti-inflammatory action }\end{array}$ \\
\hline Soluble fibrin & $\begin{array}{l}\text { Soluble complexes of fibrin desA and fibrin(ogen) } \\
\text { fragments that appear during the initial action of } \\
\text { pathologically generated thrombin on fibrinogen in blood }\end{array}$ \\
\hline Platelet aggregation & $\begin{array}{l}\text { Could be studied ex tempore by aggregometry } \\
\text { method using ADP or collagen as the most } \\
\text { common inducers. Most sensitive for showing } \\
\text { the cellular response to coagulation disorders }\end{array}$ \\
\hline
\end{tabular}


Table 4. Available treatments and new developments

\begin{tabular}{|c|c|}
\hline \multicolumn{2}{|r|}{ Pharmacologic Interventions } \\
\hline Remdesivir & Antiviral agent that is being explored as a treatment for COVID-19 \\
\hline $\begin{array}{l}\text { HIV Protease } \\
\text { Inhibitors Lopinavir/ } \\
\text { Ritonavir }\end{array}$ & $\begin{array}{l}\text { Combination therapy with lopinavir/ritonavir plus interferon beta-1b plus ribavirin } \\
\text { for the treatment of COVID-19 }\end{array}$ \\
\hline Corticosteroids & $\begin{array}{l}\text { Immunosuppression is reducing treatment time and aiding recovery from Severe } \\
\text { Acute Respiratory Syndrome }\end{array}$ \\
\hline Azithromycin & Treats certain bacterial infections, such as bronchitis, pneumonia \\
\hline Chloroquine & $\begin{array}{l}\text { Belongs to a class of drugs known as antimalarials. The Food and Drug } \\
\text { Administration (FDA) does not support the use of chloroquine for the treatment } \\
\text { or prevention of COVID-19. If the drug is used it has to be in a hospital setting }\end{array}$ \\
\hline Hydroxychloroquine & $\begin{array}{l}\text { Immunosuppressive and anti-parasite drug. It can treat and prevent malaria. It } \\
\text { can also treat lupus and arthritis. The FDA cautions against its use for COVID-19 } \\
\text { treatment }\end{array}$ \\
\hline \multicolumn{2}{|r|}{ Immune-Based Therapy } \\
\hline $\begin{array}{l}\text { Interleukin-1 } \\
\text { Inhibitors }\end{array}$ & $\begin{array}{l}\text { Approved by the FDA to treat rheumatoid arthritis, multisystem inflammatory } \\
\text { disease, T cell (CAR T-cell)-mediated cytokine release syndrome (CRS) and } \\
\text { macrophage activation syndrome (MAS) }\end{array}$ \\
\hline $\begin{array}{l}\text { Interleukin-6 } \\
\text { Inhibitors }\end{array}$ & 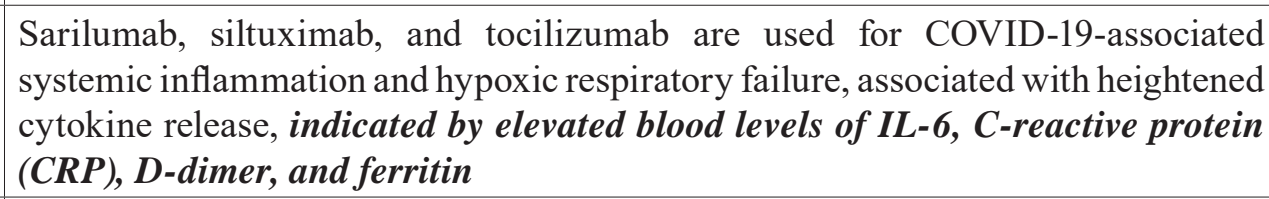 \\
\hline Kinase Inhibitors & $\begin{array}{l}\text { Have broad immunosuppressive effects. Ongoing clinical trials should help clarify } \\
\text { their role in the treatment of COVID-19 }\end{array}$ \\
\hline \multicolumn{2}{|r|}{ Adjunctive Therapy } \\
\hline $\begin{array}{l}\text { Vitamin C, Vitamin D, } \\
\text { and Zinc, Coenzyme } \\
\text { Q10, Magnesium, } \\
\text { Vitamin E Omega 3, } \\
\text { Vitamin B3 or Niacin }\end{array}$ & $\begin{array}{l}\text { Promoted for the treatment and prevention of respiratory viral infections; however, } \\
\text { their roles in treating COVID-19 are yet unproven. Supplementary therapy helps } \\
\text { at the mitochondrial level in the respiratory, cardiovascular, musculoskeletal and } \\
\text { neurological systems, supports the energy production of cells and the regulation } \\
\text { through the adenosine-5'-triphosphate (ATP) chemical energy system }\end{array}$ \\
\hline \multicolumn{2}{|r|}{ Blood-Derived Products } \\
\hline Convalescent Plasma & $\begin{array}{l}\text { Convalescent plasma that contains antibodies to severe acute respiratory syndrome } \\
\text { coronavirus } 2 \text { (SARS-CoV-2) }\end{array}$ \\
\hline $\begin{array}{l}\text { Mesenchymal } \\
\text { stem cells }\end{array}$ & Under evaluation for the treatment of COVID-19 \\
\hline Monoclonal antibodies & $\begin{array}{l}\text { Previously used to create a cocktail of antibodies that had some efficacy against } \\
\text { the Ebola virus, could work against the novel coronavirus that causes COVID-19 }\end{array}$ \\
\hline \multicolumn{2}{|r|}{ Early-stage SARS-CoV-2 coronavirus therapies: experimental } \\
\hline $\begin{array}{l}\text { IgG1 monoclonal } \\
\text { antibody }\end{array}$ & $\begin{array}{l}\text { Neutralizing IgG1 monoclonal antibody directed against the spike protein of } \\
\text { SARS-CoV-2 }\end{array}$ \\
\hline Antibody cocktail & $\begin{array}{l}\text { Cocktail approach to developing REGN-EB3, a novel triple antibody treatment for } \\
\text { Ebola that is now under regulatory review by the FDA }\end{array}$ \\
\hline Antiviral drug & $\begin{array}{l}\text { Favipiravir (Avigan; generic avifavir) antiviral was approved in 2014. Faster } \\
\text { viral clearance in the overall population, under regulatory review by the FDA for } \\
\text { treating COVID-19 }\end{array}$ \\
\hline
\end{tabular}


ment for the disease. Studying the impact of earlystage SARS-CoV-2 coronavirus therapies is critical for determining whether well-established FDA approved drugs for other human diseases would work for COVID-19 patients or new experimental drugs can help COVID-19 patients with a wide spectrum of symptoms at different levels of disease severity [41, 42].

\section{Vaccine development and categories}

At this time no vaccine is available to prevent COVID-19. However, scientists and manufacturers worldwide are accelerating COVID vaccine research activities, and pharmaceutical companies are already investing in the large-scale production of vaccines (Tables 5 and 6) [43-45].

COVID-19 was first reported in Wuhan, China, on December 31, 2019. This infection caused by the novel coronavirus is a great danger for the population worldwide since there is no known pre-immunity, no vaccine, and no specific treatment. COVID-19 is contagious, and everyone is supposed to be vulnerable. A global race has begun to develop and mass-produce an effective vaccine, with accelerated clinical trials already underway [46].

\section{Immune responses: T-cell memory from exposure to "common cold” coronaviruses (CCCs)}

Measuring immunity to SARS-CoV-2 is key for understanding COVID-19 and will guide vaccine development [47].

The normal immune response can be broken down into four main components: (i) pathogen recognition by cells of the innate immune system with (ii) cytokine release, (iii) complement activation and (iv) phagocytosis of antigens.

The immune system includes three lines of defense (Table 7) against infections by parasites, bacteria, and viruses: physical and chemical barriers, nonspecific resistance, and specific resistance [48].

The "common cold" coronaviruses (CCCs), such as HCoV-OC43, HCoV-HKU1, HCoV-NL63 and $\mathrm{HCoV}-229 \mathrm{E}$, widely circulate in the human population, are responsible for mild respiratory symptoms, and can induce immunity [49]. Potential preexisting cross-reactive T-cell immunity to SARSCoV-2 could explain the COVID-19 differences in immunity that influence herd immunity, and affect the effectiveness of COVID-19 candidate vaccines [50]. The interactions between human coronaviruses, other respiratory viruses and the SARS-CoV-2 virus should be more extensively investigated in the infected population to guide the design of COVID-19 specific therapeutics and vaccines [51]. The scientific community continuously debates the long-term protection provided by $\mathrm{T}$ cells, and therefore, the potential for reinfection by SARS-CoV-2 [52].

COVID-19 patients with severe disease compared to mild disease have increased proportions of cytotoxic follicular helper (TFH) cells and cytotoxic T helper cells (CD4-CTLs) that responded to SARS$\mathrm{CoV}-2$, as well as a reduced ratio of reactive regulatory $\mathrm{T}$ cells. Therefore, large-scale single-cell transcriptomic analysis of viral antigen-reactive CD4+ $\mathrm{T}$ cells is required to assess the effectiveness of the vaccines [53, 54].

\section{Immune-informatics}

Immune-informatics is integrating bioinformatics, structural biology, molecular biology and Molecular Dynamics (MD) simulations to verify candidate antibodies that can inhibit the coronavirus [55]. Several classes of pattern-recognition receptors (PRRs), including Toll-like receptors and cytoplasmic receptors, recognize distinct microbial components and directly activate immune cells [56].

An important part of immunological memory is T-cell memory. $\mathrm{T}$ cells that are trained to recognize specific antigens (e.g., coronaviruses) will trigger a faster and stronger immune response after encountering the same antigen. The T-cell receptor, a major histocompatibility complex (MHC) molecule, and a bound antigenic peptide, play major roles in the process of antigen-specific T-cell activation $[57,58]$. The immune-informatic approach helps to identify significant cytotoxic $\mathrm{T}$ lymphocyte and $\mathrm{B}$ cell epitopes in the 2019-novel coronavirus (2019-nCoV) surface glycoproteins. T cells and B lymphocytes play an important role in amplification of cell-mediated immune responses [59]. Advanced epitope maps (Tcell and B-cell) are required to recognize epitopes to trigger a positive resistant reaction against SARSCoV-2 [60]. The virus-specific immunological memory in T cells would trigger the B cells. B cells are at the center of the adaptive humoral immune system and are responsible for mediating the production of antigen-specific immunoglobulin (Ig). Antibodies may uncover the antigenic viral peptide epitopes that are coded in IgG glycosylation to recognize the virus glycoproteins [61]. 
Table 5. Vaccine categories and developments (as of August 4, 2020)

\begin{tabular}{|c|c|}
\hline Vaccine categories & Description \\
\hline Live Attenuated Virus & $\begin{array}{l}\text { Live but weakened ("attenuated") virus that can still reproduce (make copies } \\
\text { of itself) and activate a strong immune response but should not make people } \\
\text { sick. }\end{array}$ \\
\hline Inactivated Virus & $\begin{array}{l}\text { Inactivated virus vaccines do not provide as strong an immune response as } \\
\text { live attenuated virus vaccines, so additional doses of the vaccine may be } \\
\text { needed to get a sufficient immune response. }\end{array}$ \\
\hline Subunit Vaccines & $\begin{array}{l}\text { To treat COVID-19, potential cell-based therapies act, in general, by helping } \\
\text { the patient's immune system work better (and not overreact) through } \\
\text { releasing signals to other cells in the body to coordinate a proper reaction to } \\
\text { the infection and promote healing. }\end{array}$ \\
\hline Protein Subunit & $\begin{array}{l}\text { Protein subunit vaccines are similar to inactivated virus vaccines in that } \\
\text { they do not contain live viruses, but instead contain protein fragments of a } \\
\text { killed virus to trigger an immune response that will recognize the protein } \\
\text { fragments and therefore recognize the virus. }\end{array}$ \\
\hline Virus-Like Particles & $\begin{array}{l}\text { Uses only parts of the virus that lack the viral genetic material required to } \\
\text { replicate, but resemble the virus closely enough. They mimic the outer shell } \\
\text { of the virus to trigger an immune response without causing disease. }\end{array}$ \\
\hline Nucleic-Acid Vaccines & $\begin{array}{l}\text { This new approach uses genetic engineering to deliver nucleic acids (DNA } \\
\text { or RNA) that carry the instructions for making viral protein(s) (rather than } \\
\text { delivering the proteins themselves) into the vaccinated person's cells. Once } \\
\text { inside, those cells build the viral proteins that will trigger the immune } \\
\text { response. }\end{array}$ \\
\hline DNA-Based & $\begin{array}{l}\text { DNA-based vaccines work by inserting a genetically engineered blueprint } \\
\text { of viral gene(s) into small DNA molecules (called plasmids) for injection } \\
\text { into vaccinated people. Cells take in the DNA plasmids and follow their } \\
\text { instructions to build viral proteins, which the immune system recognizes } \\
\text { as foreign, triggering the immune response that protects against the disease. }\end{array}$ \\
\hline RNA-Based & $\begin{array}{l}\text { RNA-based vaccines work similarly to DNA-based vaccines, but instead of } \\
\text { using DNA, they use a related nucleic acid called RNA, and instead of using } \\
\text { plasmids to get into cells, they use lipid nanoparticles as delivery vehicles. } \\
\text { Once RNA vaccines are injected into vaccinated people, cells take in the } \\
\text { RNAs and build viral proteins to trigger an immune response. }\end{array}$ \\
\hline Viral Vector Vaccines & $\begin{array}{l}\text { Similar to nucleic-acid vaccines but instead of using plasmids or lipids to } \\
\text { get them into the cells of a vaccinated person, these vaccines use weakened } \\
\text { viruses (called vectors) other than the virus you are vaccinating against to } \\
\text { transport the blueprint of viral genes. }\end{array}$ \\
\hline Replicating Viral Vector & $\begin{array}{l}\text { Uses a live but weakened viral vector to carry the SARS-CoV-2 viral } \\
\text { genetic material into cells, and then the viral vector can replicate within the } \\
\text { vaccinated person's cells. The production of viral proteins will be robust, } \\
\text { producing a stronger immune response. }\end{array}$ \\
\hline Non-Replicating Viral Vector & $\begin{array}{l}\text { Non-replicating viral vector vaccines use a killed viral vector to deliver the } \\
\text { viral genetic blueprint into cells. Since the vector cannot replicate, in general } \\
\text { this type of vaccine does not provide as long-lasting immunity as replicating } \\
\text { viral vector vaccines. }\end{array}$ \\
\hline
\end{tabular}




\section{Table 6. Research activities to develop vaccines}

\begin{tabular}{|l|l|c|}
\hline $\begin{array}{c}\text { Research } \\
\text { and Clinical } \\
\text { Trial Phases }\end{array}$ & \multicolumn{1}{|c|}{ Description } & \multicolumn{1}{|c|}{$\begin{array}{c}\text { No. of COVID-19 } \\
\text { Vaccine Candidates }\end{array}$} \\
\hline Pre-Clinical & $\begin{array}{l}\text { Initial tests of a potential treatment or vaccine include various } \\
\text { tests done in the laboratory called in vitro tests and in vivo } \\
\text { studies conducted in animals to evaluate drugs or vaccines that } \\
\text { have potential to treat the disease. }\end{array}$ & 139 \\
\hline Clinical & $\begin{array}{l}\text { Vaccines and treatments advance to clinical phases when it is publicly reported that the } \\
\text { product has been dosed in a trial. Potential treatments and vaccines must be tested in } \\
\text { people to find out if they are safe and if they work to treat or prevent the disease. }\end{array}$ \\
\hline Phase I & $\begin{array}{l}\text { Clinical trials look at the safety of a potential treatment or vaccine } \\
\text { in a small group (usually less than 100) of healthy volunteers. }\end{array}$ & \multicolumn{2}{|c|}{18} \\
\hline Phase II & $\begin{array}{l}\text { Clinical trials test a potential treatment or vaccine on a large } \\
\text { (often up to several hundred) group of people who will use the } \\
\text { drug (patients) or get vaccinated (healthy volunteers), evaluating } \\
\text { whether the treatment or vaccine is safe and whether it works } \\
\text { effectively. }\end{array}$ & \multicolumn{2}{|c|}{6} \\
\hline Phase III & $\begin{array}{l}\text { Clinical trials continue to test the safety and effectiveness of a } \\
\text { treatment or vaccine but on a much larger scale, involving up to } \\
\text { several thousand people. }\end{array}$ & \\
\hline
\end{tabular}

Ta ble 7. The immune system's lines of defense

\begin{tabular}{|c|c|}
\hline \multicolumn{2}{|r|}{ Immune system defense responses } \\
\hline The first line & Involves physical barriers such as skin and mucous membranes \\
\hline Skin & $\begin{array}{l}\text { Acidity inhibits bacterial growth. Unsaturated fatty acids (known as } \\
\text { sebum) provide a protective film on the skin and inhibit growth }\end{array}$ \\
\hline Hyaluronic acid & $\begin{array}{l}\text { A naturally-occurring polysaccharide located in the skin, joints and eyes } \\
\text { that binds and retains water molecules, and is therefore essential for } \\
\text { keeping the skin hydrated }\end{array}$ \\
\hline $\begin{array}{l}\text { An enzyme produced in tears, } \\
\text { sweat, and saliva }\end{array}$ & $\begin{array}{l}\text { Lysozyme, an enzyme that breaks down cell walls and acts as an antibiotic } \\
\text { by killing bacteria }\end{array}$ \\
\hline Gastric secretion & Acids in the stomach destroy bacteria and toxins \\
\hline The second line & $\begin{array}{l}\text { The innate immune system consists of various cell types like neutrophils, } \\
\text { macrophages, and monocytes, as well as soluble factors including } \\
\text { cytokines and complement }\end{array}$ \\
\hline Fever & $\begin{array}{l}\text { Mediated by the release of pyrogenic cytokines such as tumor necrosis } \\
\text { factor (TNF), interleukin (IL)-1, IL-6, and interferons }\end{array}$ \\
\hline Inflammation & $\begin{array}{l}\text { Inflammation occurs when white blood cells flood an area invaded by } \\
\text { germs. The response includes swelling, redness, heat, and pain }\end{array}$ \\
\hline Phagocytes & Ingest and destroy microbes that pass into body tissues \\
\hline $\begin{array}{l}\text { The third line } \\
\text { Lymphocytes }\end{array}$ & $\begin{array}{l}\text { The immune system encounters antigens and develops memories of } \\
\text { them. Specific immunity adapts to specific antigens because it learns, } \\
\text { adapts, and T cells remember these antigens. When B cells encounter the } \\
\text { antibodies are produced }\end{array}$ \\
\hline
\end{tabular}




\section{Conclusion and recommendations}

Almost every government on earth has warned that daily life cannot return to normal until their populations have built up antibodies to safeguard citizens from the virus. Therefore, the most effective ways to protect yourself and others are still:

- Wearing a mask.

- Maintaining a distance of at least 6 feet from others.

- Cleaning your hands frequently and thoroughly.

- Avoiding touching your eyes, mouth, and nose.

- Covering your cough with the bend of the elbow or tissue.

\section{ЗАХВОРЮВАННЯ НА COVID-19: ПАТОГЕНЕЗ, СУДИННА ДИСФУНКЦІЯ, ІМУННІ ВІДПОВІДІ, МАРКЕРИ, ПОЛІОРГАННА НЕДОСТАТНІСТЬ, ЛІКУВАННЯ ТА ВАКЦИНАЦІ}

\section{Шандор Bарі}

Міжнародний центр досліджень та інновацій у медичній програмі Седар-Синайського медичного центру, Лос-Анджелес, Каліфорнія, США; e-mail: vari@cshs.org

Новий вірус SARS-CoV-2 становить велику небезпеку для населення у всьому світі, оскільки не існує жодного вродженого імунітету, конкретного лікування та вакцини. Тому тестування та відстеження $є$ найкращими інструментами для ізоляції інфікованих та запобігання поширенню COVID-19. Основні завдання у боротьбі 3 пандемією - це збереження життя, зменшення рівня смертності, збільшення виживаності пацієнтів у важкому та критичному стані, зменшення часу госпіталізації та прискорення одужання. У цьому огляді узагальнено дані щодо нового коронавірусу, який спричинює COVID-19, і наведено загальні відомості про симптоми, тестування, патогенез, судинну дисфункцію, лікування та вакцинацію. На даний момент немає вакцини для запобігання COVID-19. Огляд літератури свідчить про необхідність додаткових досліджень щодо взаємодії між респіраторними вірусами, коронавірусами людини та новим вірусом SARS-CoV-2 у інфікованого населення, 3 метою визначення напрямів роз- робки специфічних терапевтичних засобів i вакцин від COVID-19. Практично кожен уряд на землі усвідомив, що повсякденне життя не може повернутися до нормального стану до тих пір, поки не виникне колективного імунітету до вірусу. Вчені та виробники у всьому світі прискорюють дослідження для отримання вакцини від COVID-19 і фармацевтичні компанії вже інвестують у масштабне виробництво вакцини. Аналіз даних наведених у цьому огляді може слугувати відправною точкою для наукових проектів, присвячених дослідженню та лікуванню COVID-19. Асоціація регіональної співпраці в галузі охорони здоров'я, науки та технології (RECOOP HST), яку очолює Cedars Sinai медичний центр вже запровадила декілька наукових проектів спрямованих на краще розуміння захворювання на COVID-19.

Ключ юв і слов а: захворювання на COVID-19, симптоми, тестування, патогенез, імунні відповіді, судинна дисфункція, мультиорганна недостатність, маркери, лікування i вакцинація.

\section{References}

1. Lapointe-Shaw L, Rader B, Astley CM, Hawkins JB, Bhatia D, Schatten WJ, Lee TC, Liu JJ, Ivers NM, Stall NM, Gournis E, Tuite AR, Fisman DN, Bogoch II, Brownstein JS. Syndromic Surveillance for COVID-19 in Canada. 2020. Available from : https://doi. org/10.1101/2020.05.19.20107391

2. WHO Coronavirus Disease (COVID-19) Dashboard. Covid19.who.int. 2020. [accessed 6 Aug 2020] Available from: https://covid19.who. int/?gclid=CjwKCAjwsan5BRAOEiwALzomX zz0vRVCZlHgJsmoxG6p_DfqTxR-6sNm8yGk GQfcV4vocElSL5bGVRoCdr0QAvD_BwE

3. Hui DSC, Zumla A. Severe Acute Respiratory Syndrome: Historical, Epidemiologic, and Clinical Features. Infect Dis Clin North Am. 2019; 33(4): 869-889.

4. Assessing Risk Factors for Severe COVID-19 Illness CDC. Coronavirus Disease 2019 (COVID-19). Centers for Disease Control and Prevention. 2020. [accessed6 Aug 2020] Available from: https://www.cdc.gov/coronavirus/2019ncov/covid-data/investigations-discovery/ assessing-risk-factors.html 
5. Zhou F, Yu T, Du R, Fan G, Liu Y, Liu Z, Xiang J, Wang Y, Song B, Gu X, Guan L, Wei Y, Li H, Wu X, Xu J, Tu S, Zhang Y, Chen H, Cao B. Clinical course and risk factors for mortality of adult inpatients with COVID-19 in Wuhan, China: a retrospective cohort study. Lancet. 2020; 395(10229): 1054-1062.

6. La Vignera S, Cannarella R, Condorelli RA, Torre F, Aversa A, Calogero AE. Sex-Specific SARS-CoV-2 Mortality: Among HormoneModulated ACE2 Expression, Risk of Venous Thromboembolism and Hypovitaminosis D. Int J Mol Sci. 2020; 1(8): 2948.

7. Sharma G, Volgman AS, Michos ED. Sex Differences in Mortality from COVID-19 Pandemic: Are Men Vulnerable and Women Protected? JACC Case Rep. 2020; 2(9): 14071410.

8. Steenblock C, Todorov V, Kanczkowski W, Eisenhofer G, Schedl A, Wong ML, Licinio J, Bauer $M$, Young AH, Gainetdinov RR, Bornstein SR. Severe acute respiratory syndrome coronavirus 2 (SARS-CoV-2) and the neuroendocrine stress axis. Mol Psychiatry. 2020; 25(8): 1611-1617.

9. Patel R, Babady E, Theel ES, Storch GA, Pinsky BA, George KSt, Smith TC, Bertuzzi S. Report from the American Society for Microbiology COVID-19 International Summit, 23 March 2020: Value of Diagnostic Testing for SARS-CoV-2/COVID-19. mBio. 2020; 11(2): e00722-20.

10. Coronavirus Disease 2019 (COVID-19). Centers for Disease Control and Prevention. 2020. [accessed 6 Aug 2020] Available from: https://www.cdc.gov/coronavirus/2019-ncov/ symptoms-testing/testing.html

11. Almeida J. June Almeida (née Hart). BMJ. 2008; 336(7659): 1511.

12. Tyrrell DA, Bynoe ML. Cultivation of a Novel Type of Common-cold Virus in Organ Cultures. BMJ. 1965; 1(5448): 1467-1470.

13. Almeida JD, Tyrrell DA. The morphology of three previously uncharacterized human respiratory viruses that grow in organ culture. $J$ Gen Virol. 1967; 1(2): 175-178.

14. Shereen MA, Khan S, Kazmi A, Bashir N, Siddique R. COVID-19 infection: Origin, transmission, and characteristics of human coronaviruses. J Adv Res. 2020; 24: 91-98.
15. Cui J, Li F, Shi ZL. Origin and evolution of pathogenic coronaviruses. Nat Rev Microbiol. 2019; 17(3): 181-192.

16. Wang L, Wang Y, Ye D, Liu Q. Review of the 2019 novel coronavirus (SARS-CoV-2) based on current evidence. Int J Antimicrob Agents. 2020; 55(6): 105948.

17. Luan J, Lu Y, Gao S, Zhang L. A potential inhibitory role for integrin in the receptor targeting of SARS-CoV-2. J Infect. 2020; 81(2): 318-356.

18. Hoffmann M, Kleine-Weber H, Schroeder S, Krüger N, Herrler T, Erichsen S, Schiergens TS, Herrler G, Wu NH, Nitsche A, Müller MA, Drosten C, Pöhlmann S. SARS-CoV-2 Cell Entry Depends on ACE2 and TMPRSS2 and Is Blocked by a Clinically Proven Protease Inhibitor. Cell. 2020; 181(2): 271-280.e8.

19. Li W, Moore MJ, Vasilieva N, Sui J, Wong SK, Berne MA, Somasundaran M, Sullivan JL, Luzuriaga K, Greenough TC, Choe H, Farzan M. Angiotensin-converting enzyme 2 is a functional receptor for the SARS coronavirus. Nature. 2003; 426(6965): 450-454.

20. Flammer AJ, Anderson T, Celermajer DS, Creager MA, Deanfield J, Ganz P, Hamburg NM, Lüscher TF, Shechter M, Taddei S, Vita JA, Lerman A. The assessment of endothelial function: from research into clinical practice. Circulation. 2012; 126(6): 753-767.

21. Bonetti PO, Lerman LO, Lerman A. Endothelial dysfunction: a marker of atherosclerotic risk. Arterioscler Thromb Vasc Biol. 2003;23(2):168175.

22. Varga Z, FlammerAJ, Steiger P, Haberecker M, Andermatt R, Zinkernagel AS, Mehra MR, Schuepbach RA, Ruschitzka F, Moch H. Endothelial cell infection and endotheliitis in COVID-19. Lancet. 2020; 395(10234): 1417-1418.

23. Förstermann U, Münzel T. Endothelial nitric oxide synthase in vascular disease: from marvel to menace. Circulation. 2006; 113(13): 17081714.

24. Li H, Liu L, Zhang D, Xu J, Dai H, Tang N, $\mathrm{Su}$ X, Cao B. SARS-CoV-2 and viral sepsis: observations and hypotheses. Lancet. 2020; 395(10235): 1517-1520.

25. Thachil J, Tang N, Gando S, Falanga A, Cattaneo M, Levi M, Clark C, Iba T. ISTH interim guidance on recognition and management of 
coagulopathy in COVID-19. J Thromb Haemost. 2020; 18(5): 1023-1026.

26. Oudkerk M, Büller HR, Kuijpers D, van Es N, Oudkerk SF, McLoud TC, Gommers D, van Dissel J, Ten Cate H, van Beek EJ. Diagnosis, Prevention, and Treatment of Thromboembolic Complications in COVID-19: Report of the National Institute for Public Health of the Netherlands. Radiology. 2020; 201629.

27. Tripodi A. D-dimer testing in laboratory practice. Clin Chem. 2011; 57(9): 1256-1262.

28. Bellart J, Gilabert R, Anglès A, Piera V, Miralles RM, Monasterio J, Cabero L. Tissue factor levels and high ratio of fibrinopeptide A:Ddimer as a measure of endothelial procoagulant disorder in pre-eclampsia. Br J Obstet Gynaecol. 1999; 106(6): 594-597.

29. Stefan N, Birkenfeld AL, Schulze MB, Ludwig DS. Obesity and impaired metabolic health in patients with COVID-19. Nat Rev Endocrinol. 2020; 16(7): 341-342.

30. Ryan DH, Ravussin E, Heymsfield S. COVID 19 and the Patient with Obesity - The Editors Speak Out. Obesity (Silver Spring). 2020; 28(5): 847.

31. Sattar N, McInnes IB, McMurray JJV. Obesity Is a Risk Factor for Severe COVID-19 Infection: Multiple Potential Mechanisms. Circulation. 2020; 142(1): 4-6.

32. Malavazos AE, Corsi Romanelli MM, Bandera F, Iacobellis G. Targeting the Adipose Tissue in COVID-19. Obesity (Silver Spring). 2020; 28(7): 1178-1179.

33. Kass DA, Duggal P, Cingolani O. Obesity could shift severe COVID-19 disease to younger ages. Lancet. 2020; 395(10236): 1544-1545.

34. Francisco V, Pino J, Campos-Cabaleiro V, RuizFernández C, Mera A, Gonzalez-Gay MA, Gómez R, Gualillo O. Obesity, Fat Mass and Immune System: Role for Leptin. Front Physiol. 2018; 9: 640.

35. Ellul MA, Benjamin L, Singh B, Lant S, Michael BD, Easton A, Kneen R, Defres S, Sejvar J, Solomon T. Neurological associations of COVID-19. Lancet Neurol. 2020; S14744422(20)30221-0.

36. Abdelnour L, Abdalla ME, Babiker S. COVID 19 infection presenting as motor peripheral neuropathy. J Formos Med Assoc. 2020; 119(6): 1119-1120.

37. Bhaskar S, Bradley S, Israeli-Korn S, Menon B, Chattu VK, Thomas P, Chawla J, Kumar R,
Prandi P, Ray D, Golla S, Surya N, Yang H, Martinez S, Ozgen MH, Codrington J, Jiménez González EM, Toosi M, Mohan NH, Menon KV, Chahidi A, Hengstl SM. Chronic Neurology in COVID-19 Era: Clinical Considerations and Recommendations From the REPROGRAM Consortium. Front Neurol. 2020; 11: 664.

38. Fenrich M, Mrdenovic S, Balog M, Tomic S, Zjalic M, Roncevic A, Mandic D, Debeljak Z, Heffer M. SARS-CoV-2 DisseminationThrough Peripheral Nerves ExplainsMultiple Organ Injury. Front Cell Neurosci. 2020; 14: 229.

39. Spada C, Spera G, Riccioni M, Biancone L, Petruzziello L, Tringali A, Familiari P, Marchese M, Onder G, Mutignani M, Perri V, Petruzziello C, Pallone F, Costamagna G.A novel diagnostic tool for detecting functional patency of the small bowel: the Given patency capsule. Endoscopy. 2005; 37(9): 793-800.

40. Krstic SN, Martinov JB, Sokic-Milutinovic AD, Milosavljevic TN, KrsticMN. Capsuleendoscopy is useful diagnostic tool for diagnosing Meckel's diverticulum. Eur J Gastroenterol Hepatol. 2016; 28(6): 702-707.

41. Chakraborty R, Parvez S. COVID-19: An overview of the current pharmacological interventions, vaccines, and clinical trials. Biochem Pharmacol. 2020; 114184.

42. Files.covid19treatmentguidelines.nih.gov. 2020. [accessed 6 Aug 2020] Available from: https:// files.covid19treatmentguidelines.nih.gov/ guidelines/covid19treatmentguidelines.pdf

43. Buckland BC. The process development challenge for a new vaccine. Nat Med. 2005; 11(S4): S16-S19.

44. Chowdhury R, Islam R, Sharma HK. Development of Vaccine Against SARS-CoV-2: An Updated Review. Curr Trends Pharm Res. 2020; 7(1): 90-105.

45. Glossary. Covid-19tracker.milkeninstitute.org. 2020. [accessed 6 Aug 2020] Available from: https://covid-19tracker.milkeninstitute.org/ glossary

46. Draft landscape of COVID-19 candidate vaccines. WHO.INT. 2020. [accessed 6 Aug 2020] Available from: https://www.who.int/ publications/m/item/draft-landscape-of-covid19-candidate-vaccines

47. Meckiff BJ, Ramírez-Suástegui C, Fajardo V, Chee SJ, Kusnadi A, Simon H, Grifoni A, Pelosi E, Weiskopf D, Sette A, Ay F, Grégory 
Seumois, Ottensmeier CH, Vijayanand P. Single-cell transcriptomic analysis of SARSCoV-2 reactive $\mathrm{CD}^{+} \mathrm{T}$ cells. Available at SSRN: https://ssrn.com/abstract $=3641939$ or http:// dx.doi.org/10.2139/ssrn.3641939

48. Kate MacDonald The Immune Response, July 23, 2019 https://letstalkscience.ca/educationalresources/stem-in-context/immune-response

49. Sette A, Crotty S. Pre-existing immunity to SARS-CoV-2: the knowns and unknowns. Nat Rev Immunol. 2020; 20(8): 457-458.

50. Mateus J, Grifoni A, Tarke A, Sidney J, Ramirez SI, Dan JM, Burger ZC, Rawlings SA, Smith DM, Phillips E, Mallal S, Lammers M, Rubiro P, Quiambao L, Sutherland A, Yu ED, da Silva Antunes R, Greenbaum J, Frazier A, Markmann AJ, Premkumar L, de Silva A, Peters B, Crotty S, Sette A, Weiskopf D. Selective and cross-reactive SARS-CoV-2 T cell epitopes in unexposed humans. Science. 2020: eabd3871.

51. Nickbakhsh S, Ho A, Marques DFP, McMenamin J, Gunson RN, Murcia PR. Epidemiology of Seasonal Coronaviruses: Establishing the Context for the Emergence of Coronavirus Disease 2019. J Infect Dis. 2020; 222(1): 17-25.

52. Chen Z, Wherry EJ. T cell responses in patients with COVID-19. Nat Rev Immunol. 2020;1-8.

53. Meckiff BJ et al. "Single-cell transcriptomic analysis of SARS-CoV-2 reactive $\mathrm{CD} 4+\mathrm{T}$ cells." bioRxiv : the preprint server for biology 2020.06.12.148916. 13 Jun. 2020, doi:10.1101/2020.06.12.148916. Preprint.

54. Le Bert N, Tan AT, Kunasegaran K, Tham CYL, Hafezi M, Chia A, Chng MHY, Lin M, Tan N,
Linster M, Chia WN, Chen MI, Wang LF, Ooi EE, Kalimuddin S, Tambyah PA, Low JGH, Tan YJ, Bertoletti A. SARS-CoV-2-specific T cell immunity in cases of COVID-19 and SARS, and uninfected controls. Nature. 2020 Jul 15.

55. Magar R, Yadav P, Farimani AB. Potential Neutralizing Antibodies Discovered for Novel Corona Virus Using Machine Learning. bioRxiv 2020.03.14.992156.

56. Akira S, Uematsu S, Takeuchi O. Pathogen recognition and innate immunity. Cell. 2006; 124(4): 783-801.

57. Nanni L. Machine learning algorithms for T-cell epitopes prediction. Neurocomputing. 2006; 69(7-9): 866-868.

58. Baruah V, Bose S. Immunoinformatics-aided identification of $\mathrm{T}$ cell and $\mathrm{B}$ cell epitopes in the surface glycoprotein of 2019-nCoV. J Med Virol. 2020; 92(5): 495-500.

59. Martin TR, Wurfel MM, Zanoni I, Ulevitch R. Targeting innate immunity by blocking CD14: Novel approach to control inflammation and organ dysfunction in COVID-19 illness. EBioMedicine. 2020; 57: 102836.

60. Noorimotlagh Z, Karami C, Mirzaee SA, Kaffashian M, Mami S, Azizi M. Immune and bioinformatics identification of T cell and B cell epitopes in the protein structure of SARS-CoV-2: A systematic review. Int Immunopharmacol. 2020; 86: 106738.

61. Netea MG, van der Meer JWM. Trained Immunity: An Ancient Way of Remembering. Cell Host Microbe. 2017; 21(3): 297-300. 